\title{
THE EFFECTS OF JOB CHARACTERISTICS ON WORK ENGAGEMENT IN THE RETAIL SECTOR JHARKHAND, INDIA.
}

\author{
Puja Prasad \\ Research scholar, GITAM Institute of Management, GITAM Deemed to be University \\ Visakhapatnam, AP, India \\ Dr. K V Sandhyavani \\ Assistant Professor, GITAM Institute of Management, GITAM Deemed to be University, \\ Visakhapatnam, AP, India
}

\begin{abstract}
Employees play a key role in the success of any organization. They help achieve organizational objectives. Several studies indicate those employees who are highly engaged can help the organization respond to changes in the environment, competition and change in the workforce. The extent to which an employee believes in the mission and purpose of an organization and demonstrates commitment through their own action and attitude towards their employer is the commitment of employees. The present study investigates the relationship between job characteristic as antecedent of work engagement in the retail sectors. A sample of 71 employees from different retail sector was selected randomly. Around 100 questionnaires were distributed and only 71 questionnaires were properly filled. The standard scale of measures was used i.e. Job Diagnostics Survey (JC) and Utrecht Work Engagement Scales (UWES) was used. The Linear regression analysis revealed that job characteristics significantly affecting the work engagement. The analyses predict that Task significance is highly significant and have a positive relationship between work engagements. Skill variety, Task Identity, Autonomy has also positive relationship but feedback has no significant relationship.
\end{abstract}

Key word: Job characteristics, Work Engagement, Skill Variety, Task identity, Task Variety, Autonomy and Feedback.

Cite this Article: Ms. Puja Prasad and Dr. K V Sandhyavani, The Effects of Job Characteristics on Work Engagement in the Retail Sector Jharkhand, India. Journal of Management, 6(4), 2019, pp. 29-36.

http://www.iaeme.com/jom/issues.asp?JType=JOM\&VType=6\&IType $=4$

\section{INTRODUCTION}

Employees are the most important resource for any organization. Therefore, their behaviors must be studied, analyzed and interpreted correctly. Behavioral processes, such as employee 
commitment and job satisfaction, are of strategic importance for the performance of any organization. In addition, the nature of the work is important for both organizational and individual outcomes, so researchers must obtain a more complete understanding of the concept of work characteristics. The retail sector these days has embarked on a trip that almost doubles the size of its business with a marginal induction of skilled workforce. During this period of expansion, it continues to focus on the development of the workforce to reduce stress and retention rates in this sector. Participation in work is a construct in the positive behavior of psychology (Bakker \& Demerouti, 2008). Kahn (1990) defines commitment as a situation in which employees identify with their work. Schaufeli et al (2002) define work engagement as a mental condition of a person linked to their work, which is characterized by the existence of vigor, dedication and absorption. As indicated by Gavin and Vinten (2006), when a worker is happy with his or her activity, the representative is affirming that his or her activity needs are being met or the arrangement of employment attributes is being satisfied to make positive occupation fulfilment. Work engagement is the state in which a person is emotionally and intellectually engaged with the organization. It includes long-term emotional involvement and is a precursor to the more temporary feelings of employees, such as job satisfaction and commitment. Engaged employees come to work every day feeling in touch with their organization, have a high level of enthusiasm for their work and performance at high levels. Initially, organizations must identify the main factors of participation of their company to increase the level of participation of their employees. The acquisition and maintenance of the workforce has become a challenge for the retail sector in India. While the penetration of the retail sector in rural markets is generating huge employment opportunities, high levels of stress, working conditions and lack of professional progress are causing friction in the sector. Firth et.al. In their study, they indicated that stress and organizational stress have a stronger impact on the idea of giving up jobs in the retail sector. Retention of employees could become the biggest challenge in the growing retail sector in India. The report on the employee engagement trends (2018) of the Quantum workforce revealed that almost 35\% of employees are disconnected in their jobs. The retail sector is facing a problem in hiring employees. Research has revealed that, when an organization keeps its employees engaged, it leads to high sales, brand, organizational reputation, revenue reduction, low customer loyalty and high indicators. "Research shows that the association between the organizations plan and the work of employees, including understanding the importance of work for the success of the company, is the most vital driver of employee participation. Employees with more resources, high levels of participation are $20 \%$ better and $87 \%$ less likely to leave the organization, which indicates that the commitment is linked to the performance of the organization, it is a complex concept, with many problems that affect levels therefore, and there are many ways to encourage commitment without an adequate "kit" for all organizations. Even though each company can define employee participation differently, ultimately, the key to effective engagement will be rooted in the flexibility of the most appropriate approach for each individual company, for example, the company may consider a "best practice" and then determine the possible outcome of this practice in your workplace. Roger Simpson (2017) CEO of the retail solution writes "the results are terrible", which means that employees who are disconnected provide ordinary services that are a more difficult task to manage, have a vision of the work segment and do not help harmony and team spirit. "Today's retail business in India is growing at a remarkable speed, making the commitment and feeling of employees to build a partnership with them a vital requirement. The characteristics of the work are inherent in a work, in which the characteristics of this work have aspects or components that can lead to a complete understanding of a work, a sense of responsibility for the results of the work, a sense of concern for the impact work and also produce Positive politeness rules for employees, to further influence employee commitment. In addition, the work that has a fundamental characteristic of working with Special features will 
give employees room to become more involved in their work (Kahn, 1992). Therefore, the characteristics of the work that have special characteristics will have an impact. Increase the intrinsic motivation of employees, increase job satisfaction and reduce pressure on job applications. In addition, employees with work characteristics with special characteristics will feel in difficulty due to the applications submitted, so they can complete theirs work effectively.

\section{LITERATURE REVIEW}

Coralia Sulea, (2012) purpose of the study was to understanding the role of work engagement as a mediator between job resources. Data from three Romanian organizations were collected in a cross-sectional study and respondent were 258. Two main models (fully mediated and partially mediated) tested the role of Work Engagement as a mediator, using structural equation modelling. The results support the partially mediated model. All anticipated antecedents have a direct, and also an indirect relation with extra-role behaviours - via WE. In addition, the mediating effect was stronger for OCB than for CWB. Overall, the results show that job and personal characteristics differentially predict $\mathrm{OCB}$ and $\mathrm{CWB}$, and that employees' affectivemotivational state explains, in part, these job and personal characteristics - extra-role behaviors associations.

Vishal Gupta (2018) purpose of this paper is to develop and test a moderated-mediation model examining the relationships between motivating job characteristics, work engagement, conscientiousness and managers' turnover intentions. Data were collected using a survey questionnaire from 1,302 managers working in eight Indian private sector organizations. Structural equation modelling and hierarchical regression analysis were used to test the hypothesized relationships between the study variables. The study found evidence of the mediating role of work engagement for the relationship between motivating job characteristics and managers' turnover intentions. Conscientiousness moderated the relationship between work engagement and turnover intention. The total and indirect effects of motivating job characteristics on turnover intention were moderated by conscientiousness.

Suhartini et.al. (2019) aimed at figuring out the extent to which job characteristics, perceived organizational support and self-efficacy affect job satisfaction with work engagement serving as an intervening variable. The respondents of this research were 101 employees of the Centre for the Development and Empowerment of Educators and Educational Personnel (P4TK) of Art and Culture of Yogyakarta. The data were collected using questionnaires. The data were analyzed quantitatively and qualitatively. The quantitative analysis techniques used in this research were t-test, F-test, multiple regression analysis and path analysis. job characteristics and self-efficacy had a significant effect on work engagement and perceived organizational support did not have any significant effect on work engagement, but together it had a significant effect on work engagement.

Robbinson \& Judge (2017) defined work engagement as an extent to which an individual feels engaged, satisfied, and enthusiastic about his or her job. Work engagement is an umbrella covering various consequences in work as well as other variables that may support the organization to achieve its goals. In general, it is arguable that the idea of creating a positive attitude in an employee in working and maximizing what he or she has at the same time will open employee engagement.

Bayoumy, (2019) study aimed to investigate the relationship between job characteristics and work engagement among nursing staff in selected hospital in Cairo. Research Descriptive correlational design was used to examine the relationship between job characteristics and work engagement among nursing staff. A convenient sampling technique was used in the present study, study sample composed of 104 nursing staff teaching hospital in Cairo. Two scales were used the Job characteristics scale to measure the characteristics of the job and the work 
engagement scale to measure the levels of nurses' engagement in their work. The current study concluded that autonomy was correlated positively with absorption. Feedback is correlated positively with work engagement subscales i.e. vigor, dedication and absorption. Skill variety and task identity were correlated negatively with absorption; while task significance was not correlated with work engagement.

\section{OBJECTIVES OF THE STUDY}

1) To study the demographic profile of the respondents in Retail Sector.

2) To identify the effect of job characteristics on work engagement in Retail Sector.

\section{RESEARCH METHODOLOGY}

The item of job characteristics and work engagement were measured by using a 7 - point Likert -type scale ( $1=$ strongly disagree, $7=$ strongly agree).example of items are This job requires me to do many things at work using a variety of skills and talents, When I am working, I forget everything else around me .The sample used to measure work engagement is Utrecht Work Engagement scale (UWES) and for job characteristics Hackman \&Oldham's Job Diagnostic Survey. The study is based on primary data collected from 71 employee employees working in retail sector of Jharkhand. The random sampling technique is used for choosing the respondents. To analyse the data SPSS 23.0 was used. The descriptive Analysis and correlation method were applied to analyses the data.

\subsection{Descriptive Analysis}

Table 1- Profile of Respondents

\begin{tabular}{|c|c|c|c|}
\hline Variable & Description & $\mathrm{N}$ & $\%$ \\
\hline \multirow[t]{2}{*}{ Gender } & Male & 33 & 46.5 \\
\hline & Female & 38 & 53.5 \\
\hline \multirow[t]{3}{*}{ Age } & Under 20 & 5 & 7.0 \\
\hline & 20-29 & 62 & 87.3 \\
\hline & $30-39$ & 4 & 5.6 \\
\hline \multirow[t]{3}{*}{ Education } & 12th Degree & 20 & 28.2 \\
\hline & Graduate & 50 & 70.4 \\
\hline & Master Degree & 1 & 1.4 \\
\hline \multirow[t]{2}{*}{ Marital Status } & Unmarried & 54 & 76.1 \\
\hline & Married & 17 & 23.9 \\
\hline \multirow[t]{9}{*}{ Designation of Employee } & Coordinator & 71 & 100.0 \\
\hline & Team Member & 15 & 21.1 \\
\hline & Sales Man & 9 & 12.7 \\
\hline & Sales Women & 9 & 12.7 \\
\hline & Customer Service Associate & 6 & 8.5 \\
\hline & \begin{tabular}{|c|} 
Cashier \\
\end{tabular} & 4 & 5.6 \\
\hline & Sales Representative & 4 & 5.6 \\
\hline & Team Leader & 6 & 8.5 \\
\hline & Fashion Assistant & 7 & 9.9 \\
\hline \multirow[t]{4}{*}{ Work Experience } & $0-2$ & 3 & 4.2 \\
\hline & $2-4$ & 11 & 15.5 \\
\hline & 4-6 & 35 & 49.3 \\
\hline & $6-8$ & 22 & 31.0 \\
\hline
\end{tabular}


Table 1 explain the demographic characteristics of the respondents are given in table 1.From the study of 71 employees of retail sectors it was found that majority of respondents were female 53.5 per cent as compare to male 46.5 presents. The age group from 20-29 was more around 87.3 per cents and 76.1 per cents of respondents were unmarried. Concerning education qualification 70.4 per cents were graduate, 28.2 per cents were intermediate and only 1.4 per cents was master degree. The designation of respondents were 21.1 team member, 100 $\%$ coordinators ,sales man 12.7 per cents, sales women 12.7 per cents ,Customer service desk coordinator 8.5 per cents, Fashion assistant 9.9 and cashier 5.6 per cents. Concerning the experience of the respondent having 4-6 year experience (49.3 per cents) followed by 46-8 years' experience (31 per cents) and 2-4 years' experience ( 15.5 per cents).

Table 2- Results of Reliability Analysis

\begin{tabular}{|c|c|c|}
\hline Variable & Number Of Item & Cronbach's Alpha \\
\hline Job Characteristics & 18 & .722 \\
\hline Work Engagement & 17 & .793 \\
\hline
\end{tabular}

Table 2.1 KMO and Bartlett's Test Job Characteristics

\begin{tabular}{|c|c|c|}
\hline \multicolumn{2}{|c|}{ Kaiser-Meyer-Olkin Measure of Sampling Adequacy. } & .639 \\
\hline \multirow{3}{*}{ Bartlett's Test of Sphericity } & Approx. Chi-Square & 389.852 \\
\cline { 2 - 3 } & $\mathrm{df}$ & 105 \\
\cline { 2 - 3 } & Sig. & .000 \\
\hline
\end{tabular}

Table 2.2 KMO and Bartlett's Test Work Engagement

\begin{tabular}{|c|c|c|}
\hline \multicolumn{2}{|c|}{ Kaiser-Meyer-Olkin Measure of Sampling Adequacy. } & .769 \\
\hline \multirow{3}{*}{ Bartlett's Test of Sphericity } & Approx. Chi-Square & 679.588 \\
\cline { 2 - 3 } & $\mathrm{df}$ & 136 \\
\cline { 2 - 3 } & Sig. & .000 \\
\hline
\end{tabular}

Inferences - The construct reliability test is conducted to ensure that the scale consistently yielding the same response. The cronbach's alpha is determined as construct reliability and the minimum value recommended for Cronbach's alpha coefficient is 0.7. The cronbach's alpha value of responses on Job characteristics is determined as .722 and work engagement is .793 (Figure 2).Also in order to estimate the sampling adequacy and suitability of the data for factor analysis, KMO test and Bartlett's Test of Sphericity test was conducted using SPSS 23.00 (Figure 2), which provide with the value of 0.639 and 0.769 that is higher than the needed 0.5 and can be classified as middling (Kaiser, 1974). The chi-square value is 389.852 JC and 679.588 WE and it is highly significant ( $\mathrm{p}=0.000)$, with 105 in JC and WE 136 as a degree of freedom. 


\subsection{Correlations}

Table 3 Descriptive Statistics

\begin{tabular}{|c|c|c|c|}
\hline & Mean & Std. Deviation & N \\
\hline Total Skill Variety & 17.99 & 2.239 & 71 \\
\hline Total Task Identity & 18.23 & 2.982 & 71 \\
\hline Total Task Significance & 18.87 & 2.813 & 71 \\
\hline Total Autonomy & 16.61 & 2.891 & 71 \\
\hline Total Feedback & 13.69 & 3.236 & 71 \\
\hline Total Work Engagement & 101.75 & 10.324 & 71 \\
\hline
\end{tabular}

Table 3.1 Correlations

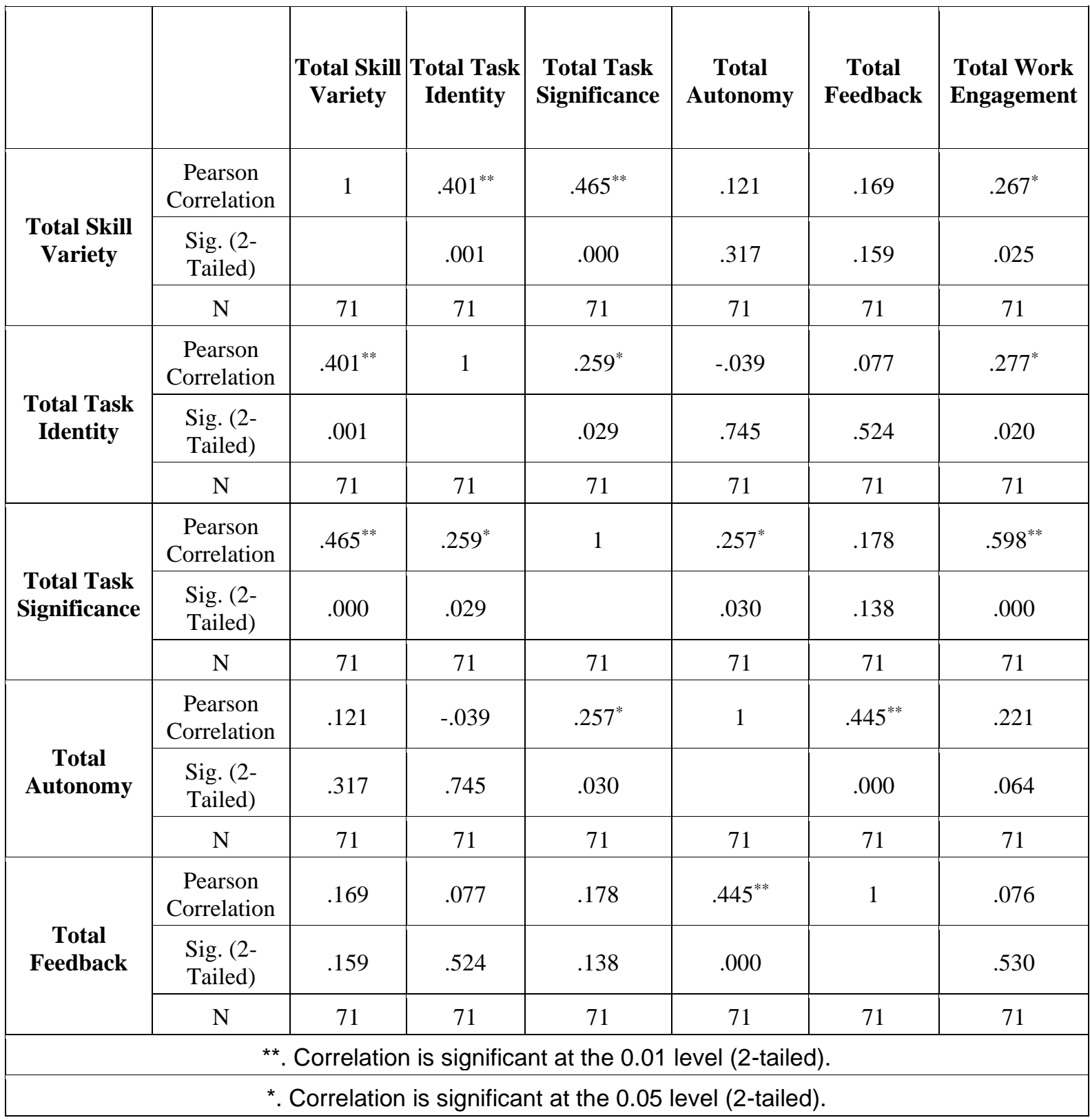


Table 3.1 finding the correlation between skill variety and work engagement $\mathrm{p}$ value $=$ 0.025 , task identity and work engagement $\mathrm{p}=0.020$, task significance $\&$ work engagement $\mathrm{p}=.000$, autonomy and work engagement $\mathrm{p}=.064$, and feedback \& work engagement $\mathrm{p}=0.530$. The correlation indicate that job characteristic 5 variable have positive and significant relationship with work engagement.

\subsection{T-Test.}

Table 4 One-Sample Test

\begin{tabular}{|c|c|c|c|c|}
\hline & \multicolumn{4}{|c|}{ Test Value $=0$} \\
\hline & $\mathrm{T}$ & $\mathrm{df}$ & Sig. (2-Tailed) & Mean Difference \\
\hline Total Skill Variety & 67.681 & 70 & .000 & 17.986 \\
\hline Total Task Identity & 51.502 & 70 & .000 & 18.225 \\
\hline Total Task Significance & 56.536 & 70 & .000 & 18.873 \\
\hline Total Autonomy & 48.403 & 70 & .000 & 16.606 \\
\hline Total Feedback & 35.643 & 70 & .000 & 13.690 \\
\hline Total Work Engagement & 83.040 & 70 & .000 & 101.746 \\
\hline
\end{tabular}

Table 4 indicate skill variety $(\mathrm{t}=67.681, \mathrm{p}=0.00)$,task identity $(\mathrm{t}=51.502, \mathrm{p}=0.00)$, task significance $(\mathrm{t}=56.536, \mathrm{p}=0.00)$, autonomy $(\mathrm{t}=48.403, \mathrm{p}=0.00)$, feedback $(\mathrm{t}=35.643, \mathrm{p}=0.00)$ were positive and significant on work engagement . The task significance is highly association with work engagement which indicate the extent to which an identifiable piece of work affects, or is important to, others within or outside the organization. An employee's knowledge of other people's dependence on the work he or she is doing is an important factor in his or her job satisfaction. If the employee know how importance and significant is there task in the organisation they are more engaged and feel more trust, motivated and respect for the organisation. The employee does their job with full responsibility, feel meaning full and complete the task in time.

\section{CONCLUSION}

On the front of the competition, Human Resources are the most important statement in all organizations. Organizations are constantly focused on involving employees through various methods. Rather, by encouraging the employee to perform the task, organizations should help them to participate more in their work and responsibilities. On the basis of the results of the research that has been carried out, it can be concluded that the characteristics of the work have a positive and significant influence on the engagement of the work. People with high job characteristics will lead to higher levels of engagement. Likewise, vice versa, people with low characteristics of job will cause a decrease in the level of employee's participation.

\section{REFERENCES}

[1] Adiarani, P. G. (2019, January). The Effects of Job Characteristics on Work Engagement. Russian Journal of Agricultural and Socio-Economic Sciences, 1(85).

[2] ANJUM, Z.-U.-Z. (2014, November 11). Job characteristics Model and job Satisfaction. International Journal of Education and Research, 2.

[3] Bayoumy, S. A. (2019, January 19). Relationship between Job characteristics and Work Engagement among Nursing Staff. International journal of Nursing Didactics, 9, 24-29. 
[4] Coralia Sulea, D. V. (2012, June 15). Work engagement as mediator between job characteristics and positive and negative extra-role behaviors. Career Development International, 17(2), 188-207.

[5] Gupta, U. A. (2018). Relationships between job characteristics, work engagement, conscientiousness and managers' turnover intentions. Personnel Review, 47 (2), 353-377.

[6] Ramesh Krishnan, S. I. (2015). Employee Work Engagement: Understanding the Role of Job Characteristics and Employee Characteristics. Journal of Applied Environmental and Biological Sciences, 4(10S), 58-67.

[7] Suhartini, A. R. (5 January 2019). The Role of Work Engagement in Moderating the Impact of Job Characteristics, Perceived Organizational Support, and Self-Efficacy on Job Satisfaction. Munich Personal RePEc Archive.

[8] Bakker, A.B. (2009). Building engagement in the workplace. In R. J. Burke \& C.L. Cooper (Eds.): The peak performing organization, 50-72.

[9] Bakker, A.B. (2011). An evidence-based model of work engagement. Current Directions in Psychological Science, 20(4), 265-269.

[10] Bakker, A.B., \& Demerouti, E. (2008). Towards a model of work engagement. Career Development International, 13(3), 209-223.

[11] Hackman, J.R. \& Oldham, G.R. (1974). The Job Diagnostic Survey: An Instrument for the Diagnosis of Jobs and the Evaluation of Job Redesign Projects. Department of Administrative Sciences: Yale University.

[12] Kahn, W.A. (1990). Psychological Conditions of Personal Engagement \& Disengagement at Work. Academy of Management Journal, 33(4), 692- 724.

[13] Luthans, F., Avey, J.B., Avolio, B.J., \& Peterson, S. J. (2010). The development and resulting performance impact of positive psychological capital. Human Resources Development Quarterly, 21(1), 41-67.

[14] Meinarty, M. (2015). Analysis of the Effect of Job Characteristic and Perceived Organizational Support on Employee Engagement (Case Study at the Head Office of Perum Perhutani). Theses. Paper 99.

[15] Nadhir, N.H.M. \& Puteh, F. (2017). Impact assessment of job characteristics model on employee engagement. E-Academia Journal, 6(1), 28-37.

[16] Noe, R. A., Hollenbeck, J.R., Gerhart, B. \& Wright, P.M. (2015). Fundamentals of Human Resource Management. New York: McGraw-Hills.

[17] Rothbard, N.P. (2001). Enriching or depleting? The dynamics of engagement in work and family roles. Administrative Science Quarterly, 46, 84-655. 